\title{
Corporate Governance, Earnings Management and Tax Avoidance: Indonesia Evidence
}

\author{
Ibrahim Husein Lubis ${ }^{1}$, Desi Adhariani ${ }^{2}$ \\ Faculty of Economics and Business, Universitas Indonesia, Indonesia ${ }^{1,2}$ \\ ilubis@deloitte.com¹, desi.adhariani@ui.ac.id²
}

\begin{abstract}
This study aims to investigate the empirical evidence on the impact of corporate governance on earnings management and tax evasion in public companies. The scope of this study is companies listed on the Indonesia Stock Exchange except those in financial, real estate, and telecommunication industries. Panel regression method was employed to run the data on samples for five-yearperiod (2012-2016). The results show that several corporate governance mechanisms play an important role in detecting earnings management, namely the institutional ownership, the percentage of independent commissioners, and percentage of audit committee members with finance/accounting background. For tax evasion, only the size of the board of commissioners that plays a role in detecting the practice. The results have practical implication on improving several corporate governance mechanisms to effectively tackle unethical practices such as earnings management and tax avoidance.
\end{abstract}

Keywords: Corporate Governance, Earnings Management, Tax Avoidance, Institutional Ownership, Independent Commissioners, Audit Committee

\section{Introduction}

One of the conflicts of interest between owners and management is represented in the manipulation of a company's financial statements; which can be in the form of earnings management. This can be detrimental to investors as the inappropriate financial statement information provided by management can bring difficulties to investors in making decisions.

Earnings management practices can also be used by companies to control their earnings that will impact taxes at the same time. Good corporate governance can play an important role in mitigating the problems of corporate earnings management and tax avoidance. This research discusses the issues of earnings management, tax evasion and corporate governance which is a development of previous research conducted by[1];[2];[3]. The objective of this research is to find empirical evidence using current data on the role of corporate governance mechanisms in mitigating earnings management and tax avoidance practices. 


\section{Method}

\subsection{Sample Selection}

The samples taken in this research are public companies listed on the Indonesia Stock Exchange (BEI) from 2012-2016. To investigate earnings management, the companies in the banking industry, other financial services, telecommunications, and real estate are excluded as they have different regulations[4]. The other reason is that the Jones model to measure the earnings management cannot be applied to the financial industry. To investigate tax avoidance, companies in the banking industry and other financial services are excluded, as well as companies experiencing losses as it will bring different consequences on the applicable tax rate.

\subsection{Research model}

Model 1: To investigate the association between corporate governance mechanisms and earnings

management

where:
$\mathrm{ADA}=\beta_{1} \mathrm{INST}+\beta_{2} \mathrm{KOMITE}+\beta_{3} \mathrm{RKOMITE}+$
1)

$$
\beta_{4} \mathrm{PINDP}+\beta_{5} \mathrm{DK}+\beta_{6} \mathrm{PBKOMITE}+\beta_{7} \mathrm{SIZE}
$$$$
+\beta_{8} \mathrm{LEV}+\beta_{9} \mathrm{BIG} 4+\beta_{10} \mathrm{CFFO}+\beta_{11} \mathrm{LOSS}+
$$$$
\beta_{12} \mathrm{ROA}+\beta_{13} \mathrm{ROA}^{2}+\varepsilon_{i t}
$$

$\begin{array}{ll}\text { ADA } & \text { : The absolute value of discretionary accruals } \\ \text { INST } & \text { : Institutional Ownership } \\ \text { COMMITTEE } & \text { : Number of audit committees } \\ \text { RKOMITE } & \text { : Number of audit committee meetings } \\ \text { PBKOMITE } & \text { : Percentage of audit committees with a financial/accounting background } \\ \text { PINDP } & \text { : Percentage of the independent board of commissioners } \\ \text { DK } & \text { : Number of boards of commissioners } \\ \text { SIZE } & : \text { Control variable, measured by the natural logarithm of total sales. } \\ \text { LEV } & : \text { Control variable, measured by the ratio of total debt to total assets } \\ \text { BIG4 } & : \text { Control variable, measured by dummy variables, } 1 \text { for Big } 4 \text { and } 0 \text { otherwise } \\ \text { CFFO } & : \text { Control variable, measured by the ratio of cash flow from operation to total } \\ \text { assets } & : \text { Control variable, measured by a dummy variable, } 1 \text { when the company } \\ \text { LOSS } & \text { suffered loss for two years and } 0 \text { otherwise } \\ \text { ROA } & : \text { Control variable, measured by the ratio of net income to total assets } \\ \text { ROA2 } & : \text { Control variable, measured by the square of net income and total asset }\end{array}$

Model 2: To investigate the association between corporate governance mechanisms and tax avoidance

$$
\begin{aligned}
\mathrm{ETR}= & \beta_{1} \mathrm{INST}+\beta_{2} \mathrm{KOMITE}+\beta_{3} \mathrm{RKOMITE}+ \\
& \beta_{4} \mathrm{PINDP}+\beta_{5} \mathrm{DK}+\beta_{6} \mathrm{PBKOMITE}+ \\
& \beta_{7} \mathrm{ROA}_{+} \beta_{8} \mathrm{BM}+\varepsilon
\end{aligned}
$$


where:

ETR : Effective Tax Rate

SIZE : Control variable, measured by the natural logarithm of total sales.

ROA : Control variable, measured by the ratio of net income to total assets

BM : Control variable, measured by the ratio of book value and market value of the stock.

\subsubsection{Dependent Variables}

a. Earnings management

Earnings management is measured by the modified Jones model:

$\mathrm{TA}_{\text {i.t }}=\mathrm{NI}_{\mathrm{i.t}}-\mathrm{CFO}_{\text {i.t }}$

where:

$\mathrm{TA}_{\mathrm{i.t}}$ : total accruals

$\mathrm{NI}_{\mathrm{i.t}}$ : net income before extraordinary item

$\mathrm{CFO}_{\mathrm{i} . \mathrm{t}}$ : cash flow from operation

$\frac{\mathrm{TA}_{\mathrm{i} . \mathrm{t}}}{\mathrm{A}_{\mathrm{i} . \mathrm{t}-1}}=\alpha_{1}\left(\frac{1}{\mathrm{~A}_{\mathrm{i} . \mathrm{t}-1}}\right)+\alpha_{2}\left(\frac{\Delta \mathrm{REV}_{\mathrm{i} . \mathrm{t}}+\Delta \mathrm{REC}_{\mathrm{i} . \mathrm{t}}}{\mathrm{A}_{\mathrm{i} . \mathrm{t}-1}}\right)+\alpha_{3}\left(\frac{\mathrm{PPE}_{\mathrm{i} . \mathrm{t}}}{\mathrm{A}_{\mathrm{i} . \mathrm{t}-1}}\right)+\alpha_{4} \mathrm{ROA}_{\mathrm{i} . \mathrm{t}-1}+\varepsilon_{\mathrm{i} . \mathrm{t}}$

where:

$\triangle \mathrm{REV}_{\mathrm{i.t}}$ : income changes

$\triangle \mathrm{REC}_{\mathrm{i} . \mathrm{t}}:$ change of receivables

$\mathrm{A}_{\mathrm{i} . \mathrm{t}-1} \quad$ : total assets

$\mathrm{PPE}_{\mathrm{i} . \mathrm{t}}$ : net property, plant and equipment

ROA $_{\text {i.t-1 }}$ : Return on Assets

Non-discretionary accrual (NDAC) is the fitted value of the above equations while the discretionary accrual (DAC) is the residual value. In accordance with [5], in this study, we use a cross-sectional model, where each model is estimated separately for each combination of years and industrial group of companies.

\section{b. Tax evasion}

The next dependent variable is tax evasion measured by ETR or effective tax rate calculated using the formula below:

Current Tax

Profit Before Interest and Tax

................................(5)

\subsubsection{Independent Variables}

\section{a. Institutional ownership}

Institutional ownership is defined as financial institutions such as insurance company, bank, pension fund, and investment banking[4].

b. Audit Committee

Audit committee consists of at least a chairman who is also an independent commissioner and two independent external members.

c. Number of audit committee meetings

The frequency of meetings between members of the audit committee is measured by the number of audit meetings within one year. 
d. Percentage of audit committees with a financial/accounting background

The proportion of an audit committee with a financial/accounting background is calculated by dividing the total number of audit committees with a financial background to the total members of the audit committee.

e. Size of boards of commissioners

The size of the board of commissioners is defined as the number of board of commissioners member in a company.

f. Percentage of the independent board of commissioners

Based on the regulations of the Indonesia Stock Exchange (BEI) Number Kep305 / BEJ / 072004 any company that has an independent commissioner of at least $30 \%$ (thirty percent) of the total members of the board of commissioners has fulfilled the corporate governance guidelines. Information on the number of independent board of commissioners obtained from annual reports of each company.

\section{Result}

\subsection{Descriptive statistics}

Descriptive statistics are used to look at the characteristics of each variable in the research model which is s presented in the following table.

Table 1. Descriptive Statistics of Earnings Management Samples

\begin{tabular}{|c|c|c|c|c|c|}
\hline Variable & $\mathbf{N}$ & Min & Max & Mean & Std. Dev \\
\hline ADA & 635 & 0.0006 & 0.7651 & 0.0769797 & 0.0842453 \\
\hline INST & 635 & 0 & 0.8104 & 0.1262 & 0.19766 \\
\hline KOMITE & 635 & 1 & 6 & 3.143307 & 0.5444864 \\
\hline RKOMITE & 635 & 0 & 59 & 8.124409 & 8.03101 \\
\hline PINDP & 635 & 0 & 0.8 & 0.3839802 & 0.1055993 \\
\hline DK & 635 & 2 & 13 & 4.618898 & 1.737403 \\
\hline PBKOMITE & 635 & 0 & 1 & 0.6586089 & 0.2262564 \\
\hline SIZE (LN) & 635 & 24.81756 & 33.19881 & 29.04166 & 1.538987 \\
\hline SIZE (Rp '000.000.000) & 635 & 59.99677 & 261855 & 12198.34 & 24984.82 \\
\hline LEV & 635 & 0.0010116 & 0.7415355 & 0.2578602 & 0.1593993 \\
\hline BIG4 & 635 & \multicolumn{4}{|c|}{ "1" = 49.375\% \& "0" = 50.625\% } \\
\hline CFFO & 635 & -0.1037274 & 0.162899 & 0.0093942 & 0.0279947 \\
\hline LOSS & 635 & \multicolumn{4}{|c|}{ "1" = $2.97 \%$ \& "0" = 97.03\% } \\
\hline ROA & 635 & -0.0656 & 0.1261 & 0.0180446 & 0.0236261 \\
\hline ROA2 & 635 & -0.2788 & 0.2691 & 0.0086457 & 0.0354059 \\
\hline
\end{tabular}

Table 2. Descriptive Statistics of Tax Evasion Samples

\begin{tabular}{|l|r|r|r|c|r|}
\hline Variable & \multicolumn{1}{c|}{ N } & \multicolumn{1}{c|}{ Min } & \multicolumn{1}{c|}{ Max } & Mean & Std. Dev \\
\hline ETR & 950 & 0.00000 & 0.9743 & 0.19521 & 0.1412516 \\
\hline INST & 950 & 0 & 0.9201 & 0.134786 & 0.2255474 \\
\hline KOMITE & 950 & 0 & 4 & 3.013684 & 0.4668371 \\
\hline RKOMITE & 950 & 0 & 59 & 6.809474 & 7.6344650 \\
\hline PINDP & 950 & 0.0000 & 0.8333 & 0.392533 & 0.1057107 \\
\hline DK & 950 & 0 & 9 & 4.382105 & 1.7986930 \\
\hline PBKOMITE & 950 & 0 & 1 & 0.665694 & 0.2370283 \\
\hline ROA & 950 & -1.322 & 0.9804 & 0.027387 & 0.0670897 \\
\hline BM & 950 & -3.8014 & 36.0007 & 2.654757 & 4.0531780 \\
\hline
\end{tabular}




\subsection{Regression results}

Prior to conducting the regression test, the data has been checked for the classical assumptions and no multicollinearity and heteroscedasticity problems found.

Table 3. Hypothesis Testing on Earnings Management

\begin{tabular}{|c|c|c|c|c|}
\hline \multicolumn{5}{|c|}{$\begin{array}{c}\mathrm{ADA}=\beta 1 \mathrm{INST}+\beta 2 \mathrm{KOMITE}+\beta 3 \mathrm{RKOMITE}+\beta 4 \mathrm{PINDP}+\beta 5 \mathrm{DK}+\beta 6 \mathrm{PBKOMITE}+ \\
\beta 7 \mathrm{SIZE}+\beta 8 \mathrm{LEV}+\beta 9 \mathrm{BIG} 4+\beta 10 \mathrm{CFFO}+\beta 11 \mathrm{LOSS}+\beta 12 \mathrm{ROA}+\beta 13 \mathrm{ROA} 2+\end{array}$} \\
\hline Variables & Sign Expectations & Coeff. & p-value & Sign. \\
\hline INST & + & 0.0465948 & 0.025 & $* *$ \\
\hline KOMITE & - & -0.0092186 & 0.196 & \\
\hline RKOMITE & + & 0.0003759 & 0.467 & \\
\hline PINDP & + & 0.0975468 & 0.004 & **** \\
\hline$\overline{\mathrm{DK}}$ & - & -0.0032727 & 0.225 & \\
\hline PBKOMITE & - & -0.0458764 & 0.008 & **** \\
\hline SIZE (LN) & - & -0.0406978 & 0.087 & $*$ \\
\hline LEV & + & 0.0406978 & 0.139 & \\
\hline BIG4 & + & 0.0034266 & 0.718 & \\
\hline CFFO & - & -0.0971696 & 0.410 & \\
\hline LOSS & - & -0.0345014 & 0.079 & $*$ \\
\hline $\mathrm{ROA}$ & + & 1.1007150 & 0.001 & **** \\
\hline ROA2 & - & -0.3223624 & 0.000 & **** \\
\hline R Squared & \multicolumn{4}{|l|}{0.1296} \\
\hline Prob > F & \multicolumn{4}{|l|}{0.0000} \\
\hline \multicolumn{5}{|c|}{ *** Significant at level 1\%; ** Significant at level 5\%; * Significant at level $10 \%$} \\
\hline \multicolumn{5}{|l|}{ Description } \\
\hline $\mathrm{ADA}$ & \multicolumn{4}{|c|}{ Absolute Discretionary accruals } \\
\hline INST & \multicolumn{4}{|l|}{ Institutional ownership } \\
\hline KOMITE & \multicolumn{4}{|l|}{ Audit committee size } \\
\hline RKOMITE & \multicolumn{4}{|c|}{ Meeting frequency of audit committee } \\
\hline PINDP & \multicolumn{4}{|c|}{ Percentage of independent commissioners } \\
\hline DK & \multicolumn{4}{|c|}{ Board of commissioners size } \\
\hline PBKOMITE & \multicolumn{4}{|c|}{ Percentage of audit committee member with finance/accounting } \\
\hline $\operatorname{SIZE}(\mathrm{LN})$ & \multicolumn{4}{|c|}{ Natural $\log$ of total asset } \\
\hline LEV & \multicolumn{4}{|l|}{ Total debt to total asset } \\
\hline BIG4 & \multicolumn{4}{|c|}{ A dummy variable, 1 for Big 4 and 0 otherwise } \\
\hline CFFO & \multicolumn{4}{|c|}{ Cash flow from operation to total asset } \\
\hline
\end{tabular}




\begin{tabular}{|l|l|}
\hline LOSS & A dummy variable, 1 for loss in 2 consecutive years and 0 otherwise \\
\hline ROA & Net income to total asset \\
\hline ROA2 & Square of Net income to total asset \\
\hline
\end{tabular}

The institutional ownership has a positive effect on earnings who states that earnings management can be efficient, not always opportunistic[4]. The size of boards of commissioners has no significant impact on earnings management, which can be seen from the p-value of 0.225 with coefficient -0.0032 . This reflects the irrelevance of board of commissioners size in detecting earnings management.

\section{Discussion}

The percentage of the independent board of commissioners has a positive effect on earnings management, as seen from the p-value of 0.004 at a significant level of $1 \%$ with a coefficient of 0.0975. This result is in line who examined the relationship between the composition of the board of commissioners and the fraudulent $f$ financial reporting and found that the fraudulent company had a lower percentage of the independent board of commissioners than the nonfraudulent company[6].

The audit committee size negatively affects earnings management which is consistent [7].The audit committee meeting has no significant effect which is consistent stating that audit committee members who meet at least four times a year cannot reduce fraud in the financial reporting process[7]. This might be because the meeting is conducted for the regulatory purpose only and hence is not able to carry out its duties and responsibilities to the maximum which causes its function and role is not effective[8].

The number of audit committees with a financial/accounting background has a negative effect on earnings management, which is consistent stating that audit committees with expertise in finance/accounting effectively oversee the possibility of earnings management[9];[7].

Table 4.Tax Evasion Hypothesis Test

$$
\begin{gathered}
\mathrm{ETR}=\beta 1 \mathrm{INST}+\beta 2 \mathrm{KOMITE}+\beta 3 \mathrm{RKOMITE}+\beta 4 \mathrm{PINDP}+\beta 5 \mathrm{DK}+\beta 6 \mathrm{PBKOMITE}+ \\
+\beta 8 \mathrm{BM}+\varepsilon
\end{gathered}
$$

\begin{tabular}{|l|c|c|r|c|}
\hline \multicolumn{1}{c|}{ Variables } & Sign expectations & \multicolumn{1}{c|}{ Coeff. } & p-value & \multicolumn{1}{c|}{ Sign. } \\
\hline INST & - & -0.02207 & 0.439 & \\
\hline KOMITE & - & -0.00949 & 0.351 & \\
\hline RKOMITE & + & 0.001226 & 0.174 & \\
\hline PINDP & + & 0.069166 & 0.166 & \\
\hline DK & + & 0.006657 & 0.063 & $* *$ \\
\hline PBKOMITE & - & -0.00715 & 0.246 & \\
\hline ROA & + & 0.095766 & 0.113 & \\
\hline BM & + & 0.001827 & 0.183 & \\
\hline R Squared & & 0.0349 & & \\
\hline Prob $>$ F & & 0.0397 & & \\
\hline
\end{tabular}




\begin{tabular}{|c|c|}
\hline \multicolumn{2}{|c|}{$* * *$ Significant at level 1\%; ** Significant at level 5\%; * Significant at level $10 \%$} \\
\hline \multicolumn{2}{|l|}{ Description: } \\
\hline ETR & Effective Tax \\
\hline INST & Institutional ownership \\
\hline KOMITE & Audit committee size \\
\hline RKOMITE & Meeting frequency of audit \\
\hline PINDP & Percentage of independent \\
\hline DK & Board of commissioners size \\
\hline PBKOMITE & $\begin{array}{l}\text { Percentage of audit committee member with } \\
\text { finance/accounting background background }\end{array}$ \\
\hline ROA & Net income to total asset \\
\hline BM & Square of net income to total asset \\
\hline
\end{tabular}

The results show that only board of commissioner size that has a significant positive effect on tax evasion, reflecting that other corporate governance mechanisms are not able to prevent tax evasion.

\section{Conclusion}

This research is conducted with the aim to investigate the role of corporate governance on earnings management and tax evasion. Based on the result of the empirical test, several corporate governance mechanisms play an important role in detecting earnings management, namely the institutional ownership, the percentage of independent commissioners, and percentage of audit committee members with finance/accounting background. As for tax evasion, only the size of the board of commissioners that plays a role in detecting the practice. The results bring practical implications on the need to improve several corporate governance mechanisms to help resolve unethical practices in the form of earnings management and tax evasion.

\section{References}

[1] A. C. Cooper dan D. Schendel, "Strategic Responses To Technological Threats," Bus. Horiz., vol. 19, no. 1, hlm. 61-69, Feb 1976.

[2] N. Fondas, "Process Innovation: Reengineering Work Through Information TechnologyProcess Innovation: Reengineering Work Through Information Technology By DavenportThomas H.. Boston, MA: Harvard Business School Press, 1993-326 pages, Itextdollar29,95," Acad. Manag. Perspect., vol. 7, no. 2, hlm. 100-103, Mei 1993.

[3] R. A. Burgelman, "Technology Strategy," dalam The Palgrave Encyclopedia of Strategic Management, Palgrave Macmillan.

[4] D. S. Elenkov, W. Judge, dan P. Wright, "Strategic Leadership And Executive Innovation Influence: An International Multi-Cluster Comparative Study,” Strateg. Manag. J., vol. 26, no. 7 , hlm. 665-682, 2005. 
[5] K. B. Lowe, K. G. Kroeck, dan N. Sivasubramaniam, "Effectiveness Correlates Of Transformational And Transactional Leadership: A Meta-Analytic Review Of The Mlq Literature," Leadersh. Q., vol. 7, no. 3, hlm. 385-425, Sep 1996.

[6] F. Damanpour dan M. Schneider, "Phases of the Adoption of Innovation in Organizations: Effects of Environment, Organization and Top Managers 1," Br. J. Manag., vol. 17, no. 3, hlm. 215-236, Sep 2006.

[7] L. D. R. Ribeiro, A. Fernandes, F. de C. Perpétuo, L. S. dos Santo, dan J. E. Storopoli, "Strategic Leadership: Top Executives and their Effects on Organizations - Uma Resenha Crítica de Finkelstein e Hambrick," Rev. Ibero-Am. Estratégia, vol. 17, no. 04, hlm. 146158, Okt 2018.

[8] R. Drazin, "Innovation and entrepreneurship: Practice and principles, by Peter F. Drucker. New York: Harper \& Row, 277 pp., Itextdollar19.95," Hum. Resour. Manage., vol. 24, no. 4, hlm. 509-512, 1985.

[9] G. Caire dan G. S. Becker, "Human Capital, A Theoretical and Empirical Analysis with Special Reference to Education," Rev. Économique, vol. 18, no. 1, hlm. 132, Jan 1967. 
